\title{
EFEKTIFITAS PROGRAM PENYULUHAN PADI PANDANWANGI ORGANIK DI DESA TEGALLEGA KECAMATAN WARUNGKONDANG KABUPATEN CIANJUR
}

\author{
Oleh : \\ Rosda Malia**) \\ Dikhrul Hakim*)
}

\begin{abstract}
Abstrak
Padi Pandanwangi merupakan varietas padi lokal unggulan Kabupaten Cianjur. Sosialisasi Padi Pandanwangi organik sudah dilakukan sejak Tahun 2000. Maka dari itu perlu adanya suatu pengkajian mengenai efektifitas program penyuluhan Padi Pandanwangi organik, agar dapat memberikan masukan bagi pengembangan Padi Pandanwangi organik. Tujuan penelitian ini untuk mengetahui karakteristik sosial ekonomi petani dan menganalisis efektifitas program penyuluhan Padi Pandanwangi organik. Penelitian ini dilaksanakan di Desa Tegallega, pada Bulan April sampai Bulan Agustus. Metode penelitian yang digunakan yaitu analisis deskriptif kualitatif. Dengan populasi 246 orang petani yang ada di Desa Tegallega dan responden sebanyak 30 orang petani padi. Hasil dari penelitian menunjukan mayoritas karakteristik sosial berada dikisaran umur 19-59 tahun, memiliki luas lahan $<0,5$ Ha, berpendidikan SD, pernah menempuh pendidikan non formal berupa penyuluhan, pelatihan, sekolah lapangan dan studi petani, tingkat kekosmopolitan 2 kali perbulan (60\%) dan efektifitas program penyuluhan Padi Pandanwangi organik tergolong cukup efektif.
\end{abstract}

Kata Kunci: Efektifitas Program Penyuluhan, Padi Pandanwangi, Pertanian Organik

\begin{abstract}
Pandanwangi Rice is a local rice varieties seeded in Cianjur Regency. Organic rice Pandanwangi Socialization has been conducted since year 2000. Therefore, there needs to be an assessment of the effectiveness of the organic program of the Padi Pandanwangi education, in order to provide input for the development of organic rice Pandanwangi. The purpose of this research is to know the socio-economic characteristics of farmers and to analyze the effectiveness of the organic Rice Pandanwangi extension program. This study was conducted in Tegallega village, in April to August. The research method used is qualitative descriptive analysis. With a population of 246 farmers in Tegallega village and respondents as many as 30 rice farmers. The results of the study showed that the majority of social characteristics were in the age of 19-59 years, has a land area of $<0.5 \mathrm{Ha}$, educated elementary school, had a non-formal education in the form of counseling, training, field schools and farmers ' studies, Cosmopolitan 2 times monthly (60\%) and effectiveness of Rice Pandanwangi Organic Counseling program is quite effective.
\end{abstract}

Keywords: effectiveness of counseling Program, Pandanwangi Rice, organic farming

*) Alumni Fakultas Sains Terapan UNSUR

**) Dosen Fakultas Sains Terapan UNSUR 


\section{PENDAHULUAN}

Penyuluhan dalam arti umum adalah ilmu sosial yang mempelajari sistem dan proses perubahan pada individu serta masyarakat agar dapat terwujud perubahan yang lebih baik sesuai dengan yang diharapkan (Setiana, 2005). Penyuluhan pertanian bagian dari sistem pembangunan pertanian yang merupakan sistem pendidikan di luar sekolah (pendidikan non formal) bagi petani beserta keluarganya dan anggota masyarakat lainnya yang terlibat dalam pembangunan pertanian. Oleh karena itu penyuluhan pertanian adalah suatu upaya untuk terciptanya iklim yang kondusif guna membantu petani beserta keluarga agar dapat berkembang menjadi dinamis. Selain itu, agar mampu untuk memperbaiki kehidupan dan penghidupannya dengan kekuatan sendiri dan pada akhirnya mampu menolong dirinya sendiri (Soeharto, 2005).

Penyuluhan pertanian menjadi sangat penting dalam perannya sebagai jembatan bagi petani. Penyuluhan diharapkan dapat menghasilkan sumber daya produksi, modal kerja, prasarana pokok disamping layanan umum lain yang dibutuhkan petani agar dapat turut serta dalam kegiatan ekonomi. Sebagai salah satu usaha untuk mengembangkan dan memajukan pembangunan pertanian, maka peran penyuluhan pertanian dalam makna agribisnis merupakan suatu tujuan pembangunan pertanian jangka panjang dalam meningkatkan taraf hidup masyarakat dengan tujuan untuk meningkatan produksi usaha tani dan nilai tambah produktivitas hasil pertanian.

Dalam Undang-Undang Nomor 16 Tahun 2006 tentang Sistem Penyuluhan Pertanian, Perikanan dan Kehutanan (SP3K) mengamanatkan bahwa penyelenggaraan penyuluhan menjadi wewenang dan tanggaung jawab pemerintah dan pemerintah daerah. Wewenang dan tanggung jawab pemerintah tersebut diwujudkan antara lain dengan menyelenggarakan revitalisasi penyuluhan pertanian yang meliputi aspek-aspek penataan kelembagaan, ketenagaan, penyelenggaraan, sarana dan prasarana, serta pembiayaan penyuluhan.

Agar revitalisasi penyuluhan pertanian dapat berjalan secara produktif, efektif dan efisien, perlu dilakukan identifikasi sumberdaya dan programprogram pembangunan pertanian, baik yang dilaksanakan oleh pemerintah, swasta maupun masyarakat. Hal tersebut diperlukan dalam rangka penyusunan rencana penyelenggaraan penyuluhan pertanian yang komprehensif dengan memadukan seluruh sumberdaya yang tersedia (PERMENTAN No. 25 tahun 2009).

Program penyuluhan pertanian merupakan rencana yang disusun secara sistematis untuk memberikan arah dan pedoman sebagai alat pengendali pencapaian tujuan penyuluhan (PERMENTAN No. 25 tahun 2009). Dengan penyuluhan yang baik dan mudah dipahami oleh petani maka transformasi ilmu yang diberikan dapat diterapkan oleh petani dalam usaha taninya (Syahputra, 2014).

Padi Pandanwangi adalah salah satu varietas padi lokal khas Cianjur. Rasa yang enak, pulen serta wangi membuatnya memiliki nilai jual cukup tinggi. Permintaan Beras Pandanwangi cukup tinggi terutama dari kalangan menengah ke atas. Umur tanaman yang lebih lama dan biaya yang lebih mahal membuat petani malas untuk membudidayakan (Putra, 2017).

Meningkatnya permintaan pangan sehat mendorong pengembangan pandanwangi organik. Salah satu daerah pengembangan pandanwangi organik yaitu Kecamatan Warungkondang khususnya di Desa Tegallega. Di Desa Tegallega terdapat beberapa kelompok tani, diantaranya: Kelompok Tani Sari Tani, Karya Barokah, Mayang Warna, Sari Barokah dan Mekar Tani. Sosialisasi Pandanwangi organik sudah dilakukan sejak Tahun 2000 namun baru dilakukan oleh sebagian kecil petani. Petani mempunyai pilihan tentang keputusan nya untuk menanam padi dengan teknik dan 
inovasi yang dapat meningkatkan hasil produksi budidaya. Budidaya Padi Pandanwangi dengan metode budidaya organik menimbulkan persepsi yang berbeda-beda sehingga tidak semua petani menerapkan. Persepsi petani tentang budidaya Padi Pandanwangi organik dipengaruhi oleh karakteristik petani, meliputi : umur, tingkat pendidikan, pendidikan non formal, luas lahan dan kekosmopolitan.

Efektifitas merupakan suatu ukuran yang memberikan gambaran seberapa jauh target dapat tercapai. Pendapat tersebut menyatakan bahwa efektifitas merupakan suatu ukuran yang memberikan gambaran seberapa jauh target yang telah ditetapkan sebelumnya oleh lembaga atau organisasi dapat tercapai. Hal tersebut sangat penting peranannya di dalam setiap lembaga atau organisasi dan berguna untuk melihat perkembangan dan kemajuan yang dicapai oleh suatu lembaga atau organisasi itu sendiri (Sedarmayanti, 2006). Sehingga perlu adanya suatu pengkajian mengenai efektifitas penyuluhan pertanian Padi Pandanwangi organik, agar dapat memberi masukan bagi pengembangan Padi Pandanwangi organik di Desa Tegallega Kecamatan Warungkondang.

Berdasarkan pemaparan diatas, tujuan penelitian untuk :

1. Mengetahui karakteristik sosial ekonomi petani di Desa Tegallega Kecamatan Warungkondang Kabupaten Cianjur.

2. Menganalisis efektifitas program penyuluhan Padi Pandanwangi organik di Desa Tegallega Kecamatan Warungkondang Kabupaten Cianjur.

\section{METODE PENELITIAN}

Penelitian dilaksanakan di Desa Tegallega Kecamatan Warungkondang Kabupaten Cianjur. Pemilihan lokasi secara segaja (purposive) karena Desa Tegallega Kecamatan Warungkondang Kabupaten Cianjur merupakan salah satu daerah pengembangan Padi Pandanwangi organik. Menurut Singaribuan dan Efendi (1995) dalam Mas'ud (2014) purposive yaitu pemilihan lokasi penelitian berdasarkan pertimbangan tertentu didasarkan pada ciri atau sifat yang sudah diketahui sebelumnya sesuai dengan kepentingan peneliti. Waktu pelaksanaan penelitian ini dimulai dari Bulan April 2019 sampai Bulan Agustus 2019.

Berbagai sumber data yang akan dimanfaatkan dalam penelitian ini sebagai berikut :

\section{Data Primer}

Menurut Narimawati 2008, data primer ialah data yang berasal dari sumber asli atau pertama. Data ini tidak tersedia dalam bentuk terkompilasi ataupun dalam bentuk file-file. Data ini harus dicari melalui narasumber atau dalam istilah teknisnya responden, yaitu orang yang dijadikan objek penelitian atau orang yang dijadikan sebagai sarana mendapatkan informasi ataupun data.

\section{Data Sekunder}

Data sekunder adalah data yang mengacu pada informasi yang dikumpulkan dari sumber yang telah ada. Sumber data sekunder adalah catatan atau dokumentasi perusahaan, publikasi pemerintah, analisis industri oleh media, situs Web, internet dan seterusnya (Sekaran, 2011).

Pengumpulan data dilakukan untuk memperoleh informasi yang dibutuhkan dalam rangka mencapai tujuan penelitian. Metode pengumpulan data dapat dilakukan dengan cara :

\section{Observasi}

Observasi adalah teknik pengumpulan data yang dilakukan melalui suatu pengamatan, dengan disertai pencatatan terhadap keadaan atau perilaku objek sasaran (Fatoni, 2006 dalam Tarigan, 2013). Peneliti melakukan pengamatan dengan indera penglihatan dan pengajuan pertanyaan-pertanyaan kepada responden. Hal ini dilakukan dengan tujuan mendapatkan data mengenai keadaan fisik objek yang menyangkut fasilitas yang ada di kawasan. 


\section{Wawancara}

Sugiono (2011), menjelaskan bahwa wawancara merupakan pertemuan dua orang untuk bertukar informasi dan ide melalui tanya jawab, sehingga dapat dikonstruksikan makna dalam suatu topik tertentu. Wawancara dilakukan dengan bertatap muka langsung dan melakukan percakapan dengan responden.

\section{Dokumentasi}

Menurut Satori (2011), studi dokumentasi yaitu mengumpulkan dokumen dan data-data yang diperlukan dalam penelitian lalu ditelaah secara intens sehingga dapat mendukung dan menambah kepercayaan dan pembuktian suatu kejadian.

\section{Angket}

Angket atau kuisioner merupakan sejumlah pertanyaan atau pernyataan tertulis tentang data faktual atau opini yang berkaitan dengan diri responden yang dianggap fakta atau kebenaran yang diketahui dan perlu dijwab oleh responden. (Anwar, 2009). Peneliti membuat angket yang berisi pertanyaan serta pernyataan tertulis yang berkaitan dengan masalah yang sedang diteliti kemudian diajukan kepada responden.

Menurut Sugiyono (2010) populasi adalah wilayah generalisasi yang terdiri atas obyek/subyek yang mempunyai kualitas dan karakteristik tertentu yang ditetapkan oleh peneliti untuk dipelajari dan kemudian di tarik kesimpulannya. Populasi dalam penelitian ini yaitu para petani yang ada di Desa Tegallega Kecamatan Warungkondang Kabupaten Cianjur yang berjumlah 246 orang.

Responden adalah orang-orang yang merespon atau menjawab pertanyaan peneliti, baik pertanyaan tertulis maupun lisan (Suharsimi Arikunto, 2003). Penentuan responden dengan metode yang bersifat non probability sampling dengan teknik purposive sampling. Menurut Sugiyono (2010), purposive sampling adalah teknik untuk menentukan sample penelitian dengan beberapa pertimbangan tertentu yang bertujuan agar data yang diperoleh nantinya bisa representatif. Dalam penelitian ini jumlah responden yang diambil sebanyak 30 orang. Menurut Cohen et al, 2007 semakin besar sampel dari besarnya populasi yang ada adalah semakin baik, akan tetapi ada jumlah batas minimal yang harus diambil oleh peneliti yaitu sebanyak 30 orang. Sebagaimana dikemukakan oleh Baley dalam Mahmud (2011) yang menyatakan bahwa untuk penelitian yang menggunakan analisis data statistik, ukuran sampel paling minimum 30 orang.

Tabel 1. Variabel dan Indikator Penelitian.

\begin{tabular}{|c|c|c|c|c|}
\hline $\begin{array}{c}\text { Tujuan } \\
\text { Penelitian }\end{array}$ & Variabel & Indikator & $\begin{array}{c}\text { Sumber } \\
\text { Data }\end{array}$ & Analisis \\
\hline $\begin{array}{l}\text { Mengetahui } \\
\text { karakteristik } \\
\text { petani padi } \\
\text { di Desa } \\
\text { Tegallega }\end{array}$ & $\begin{array}{l}\text { Karakteristik sosial ekonomi } \\
\text { adalah ciri-ciri atau sifat-sifat yang } \\
\text { dimiliki oleh seseorang petani } \\
\text { yang ditampilkan melalui pola } \\
\text { pikir, pola sikap dan pola tindakan } \\
\text { terhadap lingkungannya (Mislini, } \\
\text { 2006). } \\
\text { efektivitas merupakan suatu } \\
\text { ukuran yang memberikan } \\
\text { gambaran seberapa jauh target } \\
\text { yang telah ditetapkan sebelumnya } \\
\text { oleh lembaga atau organisasi } \\
\text { dapat tercapai(Sedarmayanti, } \\
\text { 2006). }\end{array}$ & $\begin{array}{l}\text { 1. Umur } \\
\text { 2. Luas lahan } \\
\text { 3. Pendididan formal } \\
\text { 4. Pendidikan non } \\
\text { formal } \\
\text { 5. Kekosmopolitan } \\
\text { 1. Aspek tugas atau } \\
\text { fungsi } \\
\text { 2. Aspek rencana atau } \\
\text { program } \\
\text { 3. Aspek ketentuan dan } \\
\text { peraturan } \\
\text { 4. Aspek tujuan atau } \\
\text { kondisi ideal }\end{array}$ & Primer & $\begin{array}{l}\text { Deskript } \\
\text { if }\end{array}$ \\
\hline
\end{tabular}


Analisis deskriptif adalah statistik yang digunakan untuk menganalisa data dengan cara menggambarkan atau mendeskripsikan data yang telah terkumpul sebagaimana adanya tanpa ada maksud membuat kesimpulan yang berlaku untuk umum atau generalisasi (Sugiyono, 2007). Pada penelitian ini analisis deskriftif digunakan untuk menganalisis karakteristik petani dan efektifitas program penyuluhan Padi Pandanwangi organik.
Hasil dari pengukuran dengan skala ordinal kemudian di pisahkan berdasarkan kelas yang telah ditentukan. Menurut Sudjana (2005), untuk penentuan kelas ialah rentang (data terbesar dikurangi data terkecil) dibagi banyaknya kelas/angka, yaitu :

Rentang (nilai terbesar - nilai terkecil)

$\mathrm{P}=$ Banyak Kelas / banyaknya angka

$\mathrm{P}=$ Panjang kelas $/$ interval

$$
\mathrm{P}=\frac{4-0}{5}=0,8
$$

Tabel 2. Skor Penilaian dan Tingkat Efektifitas

\begin{tabular}{cc}
\hline Nilai & Tingkat Efektifitas \\
\hline $0-0.8$ & Tidak efektif \\
$0.81-1.6$ & Kurang efektif \\
$1,61-2.4$ & Cukup efektif \\
$2,41-3.2$ & Efektif \\
$3.21-4$ & Sangat efektif \\
\hline
\end{tabular}

\section{HASIL DAN PEMBAHASAN}

\section{Gambaran Umum Lokasi Penelitian}

Secara geografis Desa Tegallega berada di Kecamatan Warungkondang, Kabupaten Cianjur. Luas wilayah Desa Tegallega yaitu 1000,350 ha, serta berada di ketinggian $700 \mathrm{~s} / \mathrm{d} 900$ mdpl. Desa Tegallega memiliki 6 RW dan 26 RT. Jumlah penduduk di Desa Tegallega sebanyak 4.848 orang. Penduduk dengan jenis kelamin laki-laki sebanyak 2.472 orang atau sebanyak $51 \%$ dan penduduk perempuan sebanyak 2.376 orang atau sebanyak $49 \%$. Total keluarga yang ada di Desa Tegallega berjumlah 1.632 keluarga. Tingkat pendidikan penduduk di Desa Tegallega umumnya adalah SD. Masyarakat Desa Tegallega sebagian besar bekerja sebagai buruh tani sebanyak 454 orang, sebagai karyawan sebanyak 290 orang dan sebagai petani sebanyak 246 orang (Profil desa, 2019)

Desa Tegallega memiliki batas wilayah sebagai berikut :

1. Sebelah utara berbatasan dengan Desa Bunikasih.
2. Sebelah selatan berbatasan dengan Desa Mekarwangi.

3. Sebelah barat berbatasan dengan Kabupaten Bogor.

4. Sebelah timur berbatasan dengan Desa Bunisari.

Desa Tegallega memiliki potensi pengembangan budidaya padi, khususnya varietas Padi Pandanwangi dan varietas unggul lainnya. Di Desa Tegallega ada 8 kelompok tani, hanya 5 kelompok tani yang membudidayakan padi. Dalam penelitian ini peneliti mengambil 5 kelompok tani yang membudidayakan padi yaitu Kelompok Tani Karya Barokah, Kelompok Tani Sari Tani, Kelompok Tani Mekar Tani, Kelompok Tani Sari Barokah dan Kelompok Tani Mayang Warna.

\section{Karakteristik Responden}

Responden dalam penelitian ini berjumlah 30 petani dari total populasi 246 petani yang ada di Desa Tegallega Kecamatan Warungkondang Kabupaten Cianjur. 
Tabel 3 Karakteristik Responden Berdasarkan Jenis Kelamin (Data primer, 2019).

\begin{tabular}{cccc}
\hline No & Jenis Kelamin & Jumlah Orang & Presentase \\
\hline 1 & Laki-Laki & 25 & $83 \%$ \\
2 & Perempuan & 5 & $17 \%$ \\
\hline & Total & $\mathbf{3 0}$ & $\mathbf{1 0 0 \%}$ \\
\hline
\end{tabular}

Mayoritas petani berjenis kelamin laki-laki yaitu sebanyak 25 petani atau $83 \%$. Hal ini berkaitan dengan posisi lakilaki yang masih memiliki tanggungjawab besar dalam mencari nafkah dalam keluarga. Kegiatan-kegiatan domestik yang dianggap non-work adalah pekerjaan yang berkaitan dengan penyelenggaraan rumah tangga dan pengasuhan anak yang secara gender ditetapkan sebagai tugas perempuan (Indrasari Tjandraningsih, 2003).

Semua petani yang dijadikan responden dalam penelitian ini beragama Islam dan bersuku bangsa Sunda. Karakteristik responden berdasarkan status perkawinan dalam penelitian ini tidak ada responden yang belum menikah, sebanyak 28 responden atau 93\% berstatus menikah dan sebanyak 2 responden atau $7 \%$ berstatus janda/duda.

\section{Karakteristik Sosial Ekonomi Responden}

Faktor-faktor Sosial Ekonomi Petani

Karakteristik sosial ekonomi adalah ciri-ciri atau sifat-sifat yang dimiliki oleh seseorang petani yang ditampilkan melalui pola pikir, pola sikap dan pola tindakan terhadap lingkungannya (Mislini, 2006). Adapun faktor sosial ekonomi meliputi : umur, luas lahan, pendidikan formal, pendidikan non formal dan kekosmopolitan. Hasil dari penelitian tentang faktor-faktor sosial ekonomi responden dapat dilihat di bawah ini.

\section{Umur Responden}

Tingkatan umur menunjukan bahwa responden tersebut merupakan penduduk atau masyarakat yang termasuk pada golongan usia belum produktif, produktif ataupun sudah tidak produktif. Menurut Shwaki dalam Astinah dkk (2013), rentang usia produktif seseorang berkisar antara 19-59 tahun. Sebelum 19 tahun termasuk ke dalam usia belum produktif dan setelah 59 tahun tidak lagi masuk usia produktif. Seseorang yang produktif akan membantu dalam kelancaran segi perekonomian dan pengembangan dalam suatu wilayah.

Tabel 4 Umur Responden (Data primer, 2019).

\begin{tabular}{cccc}
\hline No & Umur & Jumlah Orang & Presentase \\
\hline 1 & $<$ 19 Tahun & & \\
2 & $19-59$ Tahun & 27 & $90 \%$ \\
3 & $>59$ Tahun & 3 & $10 \%$ \\
\hline & Total & $\mathbf{3 0}$ & $\mathbf{1 0 0 \%}$ \\
\hline
\end{tabular}

Dari tabel 4 dapat diketahui bahwa mayoritas responden berada di kisaran 19 - 59 tahun sebanyak 27 orang dengan presentase $90 \%$, sebanyak 3 orang dengan presentase $10 \%$ berada di kisaran $>59$ tahun dan tidak ada responden yang berusia < 19 tahun. Jika dikelompokan dalam kategori umur belum produktif, produktif dan tidak produktif, maka sebagian besar responden berada di umur produktif. Karena di umur lebih dari $>59$ tahun termasuk dalam kategori umur tidak produktif dan para petani yang berada di kisaran umur $>59$ tahun sudah jarang melakukan budidaya. Menurut Ruwaida dan Endang (2015) bahwa pada usia produktif biasanya lebih cepat dalam mengadopsi suatu inovasi. Responden yang tergolong dalam usia produktif mempunyai kemampuan fisik yang optimal dan memiliki respon yang baik dalam menerima hal hal baru untuk perbaikan usahataninya. 


\section{Luas Lahan Responden}

Dalam penelitian kali ini, para responden memiliki luas lahan yang berbeda-beda. Menurut Mubyarto dalam Mulyani (2013), lahan merupakan faktor produksi yang mempunyai kedudukan yang penting bila dibandingkan dengan faktor produksi lainnya. Semakin luas lahan yang diusahakan, maka hasil produksi pun semakin tinggi. Menurut
Cahyono dalam Farhani (2009) menggolongkan petani Jawa berdasarkan luas garapan menjadi 3 golongan yaitu :

1. Petani gurem (sempit), untuk petani dengan luas lahan $<0,5$ ha

2. Petani menengah, untuk petani dengan luas lahan $0,5-1$ ha dan

3. Petani luas, untuk petani dengan luas lahan $>1$ ha

Tabel 5 Luas Lahan Responden (Data primer, 2019)

\begin{tabular}{cccc}
\hline No & Luas Lahan & Jumlah Orang & Presentase \\
\hline 1 & $<0.5$ ha & 18 & $60 \%$ \\
2 & $0.5-1$ ha & 11 & $37 \%$ \\
3 & $>1$ ha & 1 & $3 \%$ \\
\hline & Total & $\mathbf{3 0}$ & $\mathbf{1 0 0 \%}$ \\
\hline
\end{tabular}

Dari tabel 5 dapat diketahui bahwa luas lahan dalam kategori $<0,5$ ha sebanyak 18 orang dengan presentase sebesar $60 \%$ dari keseluruhan responden. Sedangkan responden dengan luas lahan $0,5-1$ ha sebanyak 11 orang dengan presentase $37 \%$ dan responden dengan luas lahan $>1$ ha sebanyak 1 orang dengan presentase 3\%. Mayoritas responden termasuk dalam kategori petani gurem (sempit) yaitu sebanyak 18 orang dengan presentase sebanyak $60 \%$.

\section{Pendidikan Formal Responden}

Pendidikan formal adalah salah satu jenis pendidikan yang terstruktur dan berjenjang yang dilaksanakan di sekolah dengan syarat tertentu yang telah ditetapkan pemerintah. Menurut Pasal 1 ayat 6 Peraturan Pemerintah Nomor 17 Tahun 2010 tentang Pengelolaan dan Penyelenggaraan Pendidikan, Pendidikan Formal adalah jalur pendidikan yang terstruktur dan berjenjang yang terdiri atas pendidikan dasar, pendidikan menengah dan pendidikan tinggi.

Tabel 6 Pendidikan Formal Responden (Data primer, 2019)

\begin{tabular}{clcc}
\hline No & \multicolumn{1}{c}{ Tingkat Pendidikan } & Jumlah Orang & Presentase \\
\hline 1 & Tidak Tamat SD & 8 & $27 \%$ \\
2 & SD & 19 & $63 \%$ \\
3 & SMP/Sederajat & & \\
4 & SMA/Sederajat & 3 & $10 \%$ \\
5 & Perguruan Tinggi & & \\
\hline \multicolumn{2}{r}{ Total } & 30 & $100 \%$ \\
\hline
\end{tabular}

Dari tabel 6 dapat diketahui bahwa sebanyak 8 orang dengan presentase $27 \%$ tidak tamat SD (Sekolah Dasar), sebanyak 19 orang dengan presentase $63 \%$ tamat SD (Sekolah Dasar), sebanyak 3 orang dengan presentase $10 \%$ tamat SMA (Sekolah Menengah Atas) /Sederajat. Tidak ada responden yang tingkat pendidikannya perguruan tinggi. Berdasarkan tingkat pendidikannya, mayoritas responden adalah tamatan SD (Sekolah Dasar) yaitu sebanyak 19 orang dengan presentase 63\% dimana dapat diakategorikan responden berpendidikan rendah. Menurut Ruwaida dan Endang (2015) tingkat pendidikan akan mempengaruhi cara berpikir seseorang yaitu cara memandang permasalahan, cara menyelesaikan permasalahan dan cara berinteraksi dengan orang lain serta dapat mempengaruhi petani dalam mengadopsi inovasi teknologi. Karena tingkat pendidikan responden rendah, sebaiknya perlu adanya pendidikan non formal seperti penyuluhan guna memberikan pengetahuan, ide dan pengalaman baru 
khususnya dibidang pertanian yang dapat menunjang pengetahuan yang tidak didapatkan di sekolah formal.

\section{Pendidikan Non Formal Responden}

Pendidikan non formal adalah jalur pendidikan yang tujuannya untuk mengganti, menambah dan melengkapi pendidikan formal. Pendidikan ini dapat diselenggarakan oleh lembaga khusus yang ditunjuk oleh pemerintah dengan berpedoman pada standar nasional pendidikan. Pengertian pendidikan non formal adalah jalur pendidikan di luar pendidikan formal yang dapat dilaksanakan secara berjenjang dan terstruktur (UU No. 20 Tahun 2003 Pasal 1 ayat 2 tentang Sistem Pendidikan Nasional).

Tabel 7 Pendidikan Non Formal Responden (Data primer, 2019).

\begin{tabular}{clcc}
\hline No & \multicolumn{1}{c}{ Pendidikan Non Formal } & Jumlah Orang & Presentase \\
\hline 1 & Penyuluhan & 3 & $10 \%$ \\
2 & Pelatihan & & \\
3 & Sekolah Lapangan & & \\
4 & Studi Petani & 27 & $90 \%$ \\
5 & Semua Pernah Ditempuh & $\mathbf{3 0}$ & $\mathbf{1 0 0 \%}$ \\
\hline \multicolumn{2}{r}{ total } & $\mathbf{3 0}$ \\
\hline
\end{tabular}

Dari tabel 7 dapat diketahui bahwa sebanyak 3 orang atau dengan presentase $10 \%$ pernah mengikuti pendidikan non formal berupa penyuluhan dan sebanyak 27 orang atau sebanyak $90 \%$ pernah menempuh pendidikan non formal berupa penyuluhan, pelatihan, sekolah lapangan dan studi petani.

\section{Frekuensi Responden Perbulan}

Pambudi (2001) kekosmopolitas adalah tingkat kemampuan seseorang dalam mencari informasi pengetahuan berupa pengalaman melihat, mendengar, membaca (media massa, cetak dan elektronik) "bergaul" maupun bepergian ke suatu tempat sehingga dapat menambah pengalaman dalam memecahkan maslah dan perubahan prilaku pribadinya.

Tabel 8 Frekuensi Kekosmopolitan Responden (Data primer, 2019)

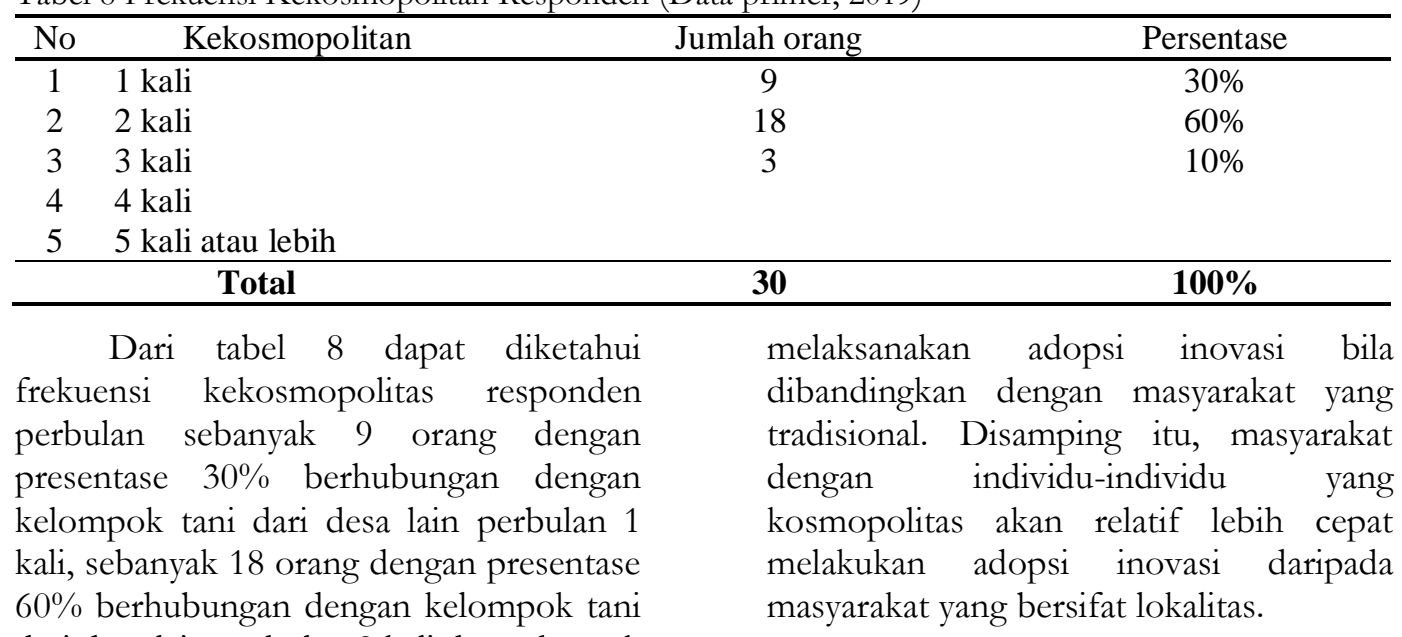

dari desa lain perbulan 2 kali dan sebanyak 3 orang dengan presentase $10 \%$ berhubungan dengan kelompok tani dari desa lain perbulan 3 kali. Menurut Soekartawi (1988) bahwa, masyarakat yang lebih modern akan relatif lebih cepat 
Efektifitas Program Penyuluhan Padi Pandanwangi Organik di Desa Tegallega Kecamatan Warungkondang Kabupaten Cianjur

Efektifitas merupakan daya pesan untuk mempengaruhi atau tingkat kemampuan pesan-pesan untuk mempengaruhi (Susanto, 2005). Aspekaspek efektifitas menurut Muasaroh (2010), bahwa efektifitas suatu program dapat dilihat :

1. Aspek tugas atau fungsi, yaitu lembaga dikatakan efektifitas jika melaksanakan tugas atau fungsinya, begitu juga suatu program pembelajaran akan efektif jika tugas dan fungsinya dapat dilaksanakan dengan baik dan peserta didik belajar dengan baik.

2. Aspek rencana atau program, yang dimaksud dengan rencana atau program disini adalah rencana pembelajaran yang terprogram, jika seluruh rencana dapat dilaksanakan maka rencana atau progarm dikatakan efektif.
3. Aspek ketentuan dan peraturan, efektifitas suatu program juga dapat dilihat dari berfungsi atau tidaknya aturan yang telah dibuat dalam rangka menjaga berlangsungnya proses kegiatannya. Aspek ini mencakup aturan-aturan baik yang berhubungan dengan guru maupun yang berhubungan dengan peserta didik, jika aturan ini dilaksanakan dengan baik berarti ketentuan atau aturan telah berlaku secara efektif .

4. Aspek tujuan atau kondisi ideal, suatu program kegiatan dikatakan efektif dari sudut hasil jika tujuan atau kondisi ideal program tersebut dapat dicapai. Penilaian aspek ini dapat dilihat dari prestasi yang dicapai oleh peserta didik.

Dalam penelitian ini, efektifitas program penyuluhan Padi Pandanwangi organik mengacu pada teori diatas. Untuk lebih jelasnya mengenai efektifitas program penyuluhan Padi Pandanwangi organik dapat dilihat pada tabel 9 berikut.

Tabel 9 Efektifitas Program Penyuluhan Padi Pandanwangi Organik

\begin{tabular}{cccc}
\hline No & Indikator & Nilai Rata-rata & Tingkatan \\
\hline 1 & Aspek tugas atau fungsi & 1,6 & Kurang efektif \\
2 & Aspek rencana atau program & 2,36 & Cukup efektif \\
3 & Aspek ketentuan dan peraturan & 2,43 & Efektif \\
4 & Aspek tujuan atau kondisi ideal & 2,16 & Cukup efektif \\
\hline & Total Rata-rata & $\mathbf{2 , 1 3}$ & Cukup efektif \\
\hline
\end{tabular}

Sumber : data primer (diolah), 2019.

Berdasarkan tabel 9. dapat diketahui aspek tugas atau fungsi mendapat skor terkecil yaitu 1,6 dan aspek ketentuan dan peraturan mendapat nilai tertinggi yaitu 2,43. Skor total rata-rata efektifitas program penyuluhan Padi Pandanwangi organik di Desa Tegallega Kecamatan Warungkondang Kabupaten Cianjur mendapat skor 2,13 dan berada dikategori cukup efektif. Responden menilai demikian karena : belum semua lembaga berperan dalam program penyuluhan, penyuluhan Padi Pandanwangi di Desa Tegallega Kecamatan Warungkondang Kabupaten Cianjur masih jarang dilakukan, bantuan hanya berupa pemberian pupuk.
Eti Wulanjari dkk, 2016 menyatakan bahwa karakteristik responden memegang peran penting dalam menentukan efektifitas SL perbenihan. Hasil penelitian menunjukkan bahwa karakteristik responden yang berhubungan nyata dengan efektifitas SL adalah pendidikan. Pendidikan terakhir berhubungan sangat nyata dengan efektifitas sekolah lapang. Hal ini berarti semakin tinggi pendidikan responden maka semakin tinggi pula efektifitas sekolah lapangnya, dan tujuan sekolah lapang semakin tercapai.

Dalam penelitian ini mayoritas pendidikan formal responden hanya lulus SD sehingga tingkat efektifitasnya hanya 
ditahap cukup efektif, perlu dilakukan penyuluhan yang berulang kali agar dapat mencapai penyuluhan yang efektif. Efferson dalam Syafruddin (2003) menyatakan bahwa tingkat pendidikan baik formal maupun non formal besar sekali pengaruhnya terhadap penyerapan ide-ide baru, sebab pengaruh pendidikan terhadap seseorang akan memberikan suatu wawasan yang luas, sehingga petani tidak mempunyai sifat yang tidak terlalu tradisional. Jadi tingkat pendidikan masyarakat merupakan salah satu aspek yang mempengaruhi pola pikir seseorang dalam menentukan keputusan menerima inovasi baru, karena semakin tinggi tingkat pendidikan seseorang diharapkan dapat berpikir lebih baik dan mudah menyerap inovasi pertanian yang berkaitan dengan pengembangan usahataninya. Mereka yang berpendidikan tinggi adalah relatif lebih cepat dalam melaksanakan adopsi inovasi. Begitu pula sebaliknya mereka yang berpendidikan rendah, agak sulit dan memakan waktu yang relatif lama untuk mengadakan perubahan. Rincian hasil penelitian dari masing-masing indikator dapat dilihat dibawah ini.

\section{Aspek Tugas atau Fungsi}

Tabel 10 Aspek Tugas atau Fungsi.

\begin{tabular}{|c|c|c|c|c|c|c|c|c|}
\hline \multirow[t]{2}{*}{ No } & \multirow{2}{*}{ Indikator } & \multicolumn{5}{|c|}{ Frekuensi Jawaban } & \multirow{2}{*}{$\begin{array}{l}\text { Nilai Rata- } \\
\text { rata }\end{array}$} & \multirow{2}{*}{$\begin{array}{c}\text { Tingkat } \\
\text { Efektivitas }\end{array}$} \\
\hline & & 0 & 1 & 2 & 3 & 4 & & \\
\hline \multirow[t]{5}{*}{1} & Aspek tugas atau fungsi & & & & & & & \\
\hline & $\begin{array}{l}\text { a. Peran GAPOKTAN dalam } \\
\text { propgram penyuluhan Padi } \\
\text { Pandanwangi organik }\end{array}$ & 0 & 1 & $\begin{array}{l}1 \\
2\end{array}$ & 17 & 0 & 2,53 & efektif \\
\hline & $\begin{array}{l}\text { b. Peran BP3K dalam } \\
\text { propgram penyuluhan Padi } \\
\text { Pandanwangi organik }\end{array}$ & 0 & 2 & $\begin{array}{l}2 \\
5\end{array}$ & 3 & 0 & 2,03 & cukup efektif \\
\hline & $\begin{array}{l}\text { c. Peran Desa dalam propgram } \\
\text { penyuluhan Padi } \\
\text { Pandanwangi organik }\end{array}$ & $\begin{array}{l}2 \\
2\end{array}$ & 8 & 0 & 0 & 0 & 0,26 & tidak efektif \\
\hline & Rata-rata & & & & & & 1,6 & kurang efektif \\
\hline
\end{tabular}

Sumber : data primer (diolah), 2019.

Aspek tugas atau fungsi dinilai berdasarkan peran dari : GAPOKTAN, BP3K dan desa dalam program penyuluhan Padi Pandanwangi organik. Rata-rata skor mengenai peran GAPOKTAN sebesar 2,53. Responden menilai peran GAPOKTAN efektif dalam program penyuluhan Padi Pandanwangi organik karena GAPOKTAN selalu memberikan informasi tentang penyuluhan yang akan dilakukan. Ratarata skor peran BP3K sebesar 2,03. Responden menilai peran BP3K dalam program penyuluhan Padi Pandanwangi organik cukup efektif karena beberapa kali BP3K melakukan penyuluhan. Ratarata skor mengenai peran desa sebesar 0,26 . Responden menilai peran desa tidak efektif dalam program penyuluhan Padi Pandanwangi organik karena desa dinilai belum memberikan kontribusinya terhadap penyuluhan Padi Pandanwangi Organik. Total rata-rata skor aspek tugas atau fungsi sebesar 1,6. Nilai tersebut berarti bahwa aspek tugas atau fungsi kurang efektif karena belum semua lembaga berperan dalam program penyuluhan Padi Pandanwangi organik.

\section{Aspek Rencana atau Program}

Aspek rencana atau program dinilai berdasarkan : program penyuluhan Padi Pandanwangi organik, penyuluhan Padi Pandanwangi organik, pelatihan Padi Pandanwangi organik, percontohan (demplot) Padi Pandanwangi organik dan pendampingan Padi Pandanwangi organik. Hasil penelitian dari indikator aspek rencana atau program disajikan dalam tabel 11 . 
Tabel 11 Aspek Rencana atau Program.

\begin{tabular}{|c|c|c|c|c|c|c|c|c|}
\hline \multirow{2}{*}{ No } & \multirow{2}{*}{ Indikator } & \multicolumn{5}{|c|}{ Frekuensi Jawaban } & \multirow{2}{*}{$\begin{array}{l}\text { Nilai Rata- } \\
\text { rata }\end{array}$} & \multirow{2}{*}{$\begin{array}{l}\text { Tingkat } \\
\text { Efektivitas }\end{array}$} \\
\hline & & $\mathbf{0}$ & 1 & 2 & 3 & 4 & & \\
\hline \multirow[t]{7}{*}{2} & Aspek rencana atau program & & & & & & & \\
\hline & $\begin{array}{l}\text { a. Program penyuluhan Padi } \\
\text { Pandanwangi organik }\end{array}$ & & 3 & 15 & 11 & 1 & 2,23 & cukup efektif \\
\hline & $\begin{array}{l}\text { b. Penyuluhan Padi } \\
\text { Pandanwangi organik }\end{array}$ & & 6 & 12 & 12 & & 2,2 & cukup efektif \\
\hline & $\begin{array}{l}\text { Pelatihan Padi } \\
\text { Pandanwangi organik }\end{array}$ & & 1 & 12 & 12 & 5 & 2,7 & efektif \\
\hline & $\begin{array}{l}\text { d. Percontohan (demplot) } \\
\text { Padi Pandanwangi organik }\end{array}$ & 2 & 4 & 5 & 13 & 6 & 2,56 & efektif \\
\hline & $\begin{array}{l}\text { e. Pendampingan Padi } \\
\text { Pandanwangi organik }\end{array}$ & & 4 & 18 & 8 & & 2,13 & cukup efektif \\
\hline & Rata-rata & & & & & & 2,36 & cukup efektif \\
\hline
\end{tabular}

Sumber : data primer (diolah), 2019.

Dari tabel 11 dapat diketahui bahwa nilai rata rata program penyuluhan Padi Pandanwangi organik sebesar 2,23. Responden menilai bahwa program penyuluhan Padi Pandanwangi organik cukup efektif. Nilai rata-rata penyuluhan Padi Pandanwangi organik sebesar 2,2. Responden menilai penyuluhan Padi Pandanwangi organik cukup efektif karena penyuluhan Padi Pandanwangi organik telah diberikan oleh penyuluh lapangan. Nilai rata-rata pelatihan Padi Pandanwangi organik sebesar 2,7. Nilai tersebut berarti bahwa responden menilai pelatihan Padi Pandanwangi organik efektif karena pelatihan Padi Pandanwangi membantu para petani dalam melakukan budidaya Padi Pandanwangi organik. Nilai rata-rata percontohan (demplot) sebesar 2,56. Responden menilai percontohan (demplot) efektif karena dari percontohan (demplot) ini para petani bisa melihat cara dan hasil dari budidaya Padi Pandanwangi organik. Nilai rata-rata pendampingan Padi Pandanwangi organik sebesar 2,13.
Responden menilai pendampingan Padi Pandanwangi organik cukup efektif karena penyuluh lapangan memberikan pendampingan serta arahan dan membantu memecahkan masalah yang ditemui petani pada saat budidaya Padi Pandanwangi organik. Total rata-rata skor aspek rencana atau program sebesar 2,36. Nilai tersebut menyatakan bahwa aspek rencana atau program cukup efektif.

\section{Aspek Ketentuan atau Peraturan}

Aspek ketentuan dan peraturan, efektifitas suatu program juga dapat dilihat dari berfungsi atau tidaknya aturan yang telah dibuat dalam rangka menjaga berlangsungnya proses kegiatannya. Aspek ini mencakup aturan-aturan baik yang berhubungan dengan guru maupun yang berhubungan dengan peserta didik, jika aturan ini dilaksanakan dengan baik berarti ketentuan atau aturan telah berlaku secara efektif. Indikator berdasarkan aspek ketentuan dan peraturan disajikan dalam tabel 12.

Tabel 12 Aspek Ketentuan atau Peraturan

\begin{tabular}{|c|c|c|c|c|c|c|c|c|}
\hline \multirow[t]{2}{*}{ No } & \multirow[t]{2}{*}{ Indikator } & \multicolumn{5}{|c|}{ Frekuensi Jawaban } & \multirow{2}{*}{$\begin{array}{c}\text { Nilai } \\
\text { Rata-rata }\end{array}$} & \multirow{2}{*}{$\begin{array}{l}\text { Tingkat } \\
\text { Efektivitas }\end{array}$} \\
\hline & & 0 & 1 & 2 & 3 & 4 & & \\
\hline \multirow[t]{3}{*}{3} & Aspek ketentuan dan peraturan & & & & & & & \\
\hline & $\begin{array}{l}\text { Kebijakan lembaga dalam } \\
\text { penyuluhan Padi Pandanwangi } \\
\text { organik }\end{array}$ & & 3 & 15 & 8 & 4 & 2,43 & efektif \\
\hline & Rata-rata & & & & & & 2,43 & efektif \\
\hline
\end{tabular}

Sumber : data primer (diolah), 2019 
Dari tabel 12 dapat diketahui bahwa nilai rata-rata aspek ketentuan dan peraturan sebesar 2,43. Responden menilai kebijakan lembaga dalam penyuluhan Padi Pandanwangi organik efektif karena beberpa kali BP3K memberikan bantuan berupa pupuk dan alat pengendali hama kepada para petani.
Aspek Tujuan atau Kondisi Ideal

Aspek tujuan atau kondisi ideal, suatu program kegiatan dikatakan efektif dari sudut hasil jika tujuan atau kondisi ideal program tersebut dapat dicapai. Penilaian aspek ini dapat dilihat dari prestasi yang dicapai oleh peserta didik. Indikator berdasarkan aspek tujuan atu kondisi ideal disajikan dalam tabel 13.

Tabel 13 Aspek Tujuan atau Kondisi Ideal

\begin{tabular}{|c|c|c|c|c|c|c|c|c|}
\hline \multirow[t]{2}{*}{ No } & \multirow[t]{2}{*}{ Indikator } & \multicolumn{5}{|c|}{ Frekuensi Jawaban } & \multirow[t]{2}{*}{ Nilai Rata-rata } & \multirow{2}{*}{$\begin{array}{c}\text { Tingkat } \\
\text { Efektivitas }\end{array}$} \\
\hline & & 0 & 1 & 2 & 3 & 4 & & \\
\hline \multirow[t]{2}{*}{4} & $\begin{array}{lr}\text { Kondisi } & \text { sekarang } \\
\text { kondusif } & \text { untuk } \\
\text { pertanian } & \text { Padi } \\
\text { Pandanwangi } & \text { organik }\end{array}$ & & 5 & 15 & 10 & & 2,16 & cukup efektif \\
\hline & Rata-rata & & & & & & 2,16 & cukup efektif \\
\hline
\end{tabular}

Sumber : data primer (diolah), 2019.

Dari tabel 13 dapat diketahui bahwa nilai rata-rata aspek tujuan atau kondisi ideal sebesar 2,16. Responden menilai kondisi lingkungan sesuai untuk budidaya Padi Pandanwangi organik. Dikarenakan Padi Pandanwangi dapat tumbuh optimal di Desa Tegallega Kecamatan Warungkondang Kabupaten Cianjur. Lembaga (GAPOKTAN dan BP3K) berperan dalam penyuluhan Padi Pandanwangi organik.

\section{KESIMPULAN}

Bedasarkan hasil dan pembahasan yang telah dijelaskan pada bab sebelumnya, maka penelitian ini menyimpulkan beberapa hal sebagai berikut :

1. Karakteristik sosial ekonomi petani responden :

a. Mayoritas responden berada dikisaran umur 19-59 sebanyak 27 orang $(90 \%)$.

b.Luas lahan didominasi oleh petani yang memiliki luas lahan $<0,5$ ha sebanyak 18 orang (60\%).Pendidikan formal mayoritas responden (63\%) tamat SD (Sekolah Dasar).

c. Mayoritas responden pernah menempuh pendidikan non formal berupa penyuluhan, pelatihan, sekolah lapangan dan studi petani sebanyak $27 \quad$ orang $(90 \%)$
d.Mayoritas responden $\quad(60 \%)$ berhubungan dengan kelompok tani dari desa lain perbulan 2 kali.

2. Efektivitas program penyuluhan Padi Pandanwangi organik di Desa Tegallega Kecamatan Warungkondang Kabupaten Cianjur :

a. Aspek tugas atau fungsi mendapat skor terkecil yaitu 1,6.

b. Aspek ketentuan dan peraturan mendapat nilai tertinggi yaitu 2,43.

c. Skor total rata-rata efektivitas program penyuluhan Padi Pandanwangi organik di DesaTegallega Kecamatan Warungkondang Kabupaten Cianjur mendapat skor 2,13 dan berada dikategori cukup efektif.

\section{DAFTAR PUSTAKA}

Arikunto, Suharsimi. 2003. Prosedur Penelitian, Suatu Praktek. Jakarta: Bina Aksara.

Farhani, Ardianto. 2010. Motivasi Sosial Ekonomi Petani Beralih Pekerjaan Dari Sektor Pertanian ke Sektor industri Kerajinan Mebel di Desa Serenan Kecamatan Juwiring Kabupaten Klaten. Skripsi. Universitas Sebelas Maret. Surakarta. 
Mislini, 2006. Analisis Jaringan Komunikasi pada Kelompok Swadaya Masyarakat. Kasus KSM di Desa Taman Sari Kabupaten Bogor, Provinsi Jawa Barat. Bogor:

Program Pascasarjana, Institut Pertanian Bogor.

2001. Metodologi Penelitian Kualitatif. Bandung:

Remaja Rosdakarya.

Muasaroh, Latifatul. 2010. Aspek - Aspek Efektivitas. Yogyakarta: Literatur Buku.

Mulyani, A., M. Sarwani, I. Las, F. Agus, D. Kuncoro, and M. Sahidin. 2013. Kajian mendalam dan penajaman data serta potensi alih fungsi lahan. Laporan Akhir No. 20/LA/BBSDLP/2013. Balai Besar Litbang Sumberdaya Lahan Pertanian. Bogor.

Narimawati, umi. 2008. Metodologi Penelitian Kualitatif dan Kuantitatif, Teori dan Aplikasi. Bandung: Agung Media.

Pemerintah Republik Indonesia, 2003. Undang Undang Republik Indonesia Nomor 20 tahun 2003 tentang Sistem Pendidikan Nasional (SISDIKNAS). Jakarta

Pemerintah Republik Indonesia, 2010. Peraturan Pemerintah Republik Indonesia Nomor 17 tahun 2010 tentang Pengelolaan dan Penyelenggaraan Pendidikan. Jakarta.

Peraturan Mentri Pertanian, 2009. Nomor 25/Permentan/OT.140/5/2009 tentang Pedoman Penyusunan Programa Penyuluhan Pertanian.

Putra, Helmi. 2017. Tingkat Adopsi Petani Terhadap Penerapan Padi Pandanwangi Organik
(Studi Kasus di Desa Tegallega Kecamatan Warungkondan). Skripsi. Universitas Suryakancana. Cianjur.

Satori Djam'an, 2011, Metode Penelitian Kualitatif. Bandung : Alfabeta.

Sedarmayanti. 2006. Sumber Daya Manusia dan Produktivitas Kerja. Bandung: Mandar Maju

Sekaran, uma.2011.metode penelitian untuk bisnis. Jakarta: salemba empat.

Setiana. L. 2005. Teknik Penyuluhan Dan Pemberdayaan Masyarakat. Bogor : Ghalia Indonesia.

Soeharto, N. P. 2005. Progam Penyuluhan Pertanian (materi dalam diklat dasar - dasar funsional penyuluh). Jakarta : PT. Gramedia Pustaka.

Sudjana. 2005. Metoda Statistika. Bandung. Tarsito.

Sugiyono. 2007. Metode Penelitian Kuantitatif Kualitatif dan R\&D. Bandung: Alfabeta. . 2010. Metode Penelitian Pendidikan Pendekatan

Kuantitatif, kualitatif, dan R\&D. Bandung: Alfabeta

2011. Metode Penelitian Kuantitatif, Kualitatif dan R\&D. Bandung: Afabeta

Syahputra, Edi. 2014. Efektivitas Program Penyuluhan Pertanian Lapangan di Wilayah Kerja Balai Penyuluhan Pertanian (WKBPP) Kecamatan Beutong Kabupaten Nagan Raya. Skripsi. Universitas Teuku Umar. Meulaboh.

Tarigan, H. G. 2013. Menulis sebagai suatu keterampilan berbahasa. Bandung: Angkasa.

Undang-undang No. 16 Tahun 2006 Tentang Sistem Penyuluhan Pertanian,Perikanan dan Kehutanan. 